\title{
FUNGSI ORENG DALAM BAHASA LAMAHOLOT DI IMULOLONG KABUPATEN LEMBATA NUSA TENGGARA TIMUR
}

\author{
A lexander Bala Gawen \\ Program Studi Pendidikan Bahasa dan Sastra Indonesia \\ Fakultas Keguruan dan IImu Pendidikan, Universitas Flores \\ Pos-el: abggawen@yahoo.com
}

\begin{abstract}
A bstrak
Masalah penelitian ini adalah menemukan dan mendeskripsikan fungsi oreng dalam bahasa Lamaholot di Imulolong Kabupaten Lembata, Nusa Tenggara Timur. Inti penelitiannya yaitu pada aspek untuk apa bertutur atau untuk apa berbahasa. Dengan demikian, teori yang digunakan adalah teori pragmatik. Berdasarkan teori pragmatik sejumlah data yang dikumpulkan akan dianalisis dengan mempertimbangkan konteks terjadinya tuturan tersebut. Untuk mendapatkan data tentang fungsi oreng, peneliti menggunakan metode naturalistik di mana sampelnya dipilih secara purposif. Penelitian naturalistik menekankan pada kealamiahan sumber data dengan mengandalkan seluruh gejala sosial kemasyarakatan sebagai sumber penghimpunan data, sehingga membutuhkan pengamatan berperan serta (participant observation). Selain itu, peneliti menggunakan teknik rekam dan melakukan penyimakan berpartisipasi melalui metode simak libat cakap. Pengumpulan data juga dengan menyandingkan pendekatan emik dan etik. Hasil penelitian menunjukkan bahwa fungsi oreng berkenaan dengan empat fungsi pragmatik, yakni (1) fungsi direktif, (2) fungsi ekspresif, (3) fungsi estetik, dan (4) fungsi komunikatif. Fungsi direktif meliputi fungsi memerintah, melarang, permintaan, menasihati, dan presilaan. Fungsi ekspresif meliputi fungsi harapan, kesetiaan atau loyalitas. Fungsi estetik meliputi fungsi simile, repetisi, sinekdoki, dan personifikasi. Fungsi komunikatif meliputi fungsi informatif.
\end{abstract}

Kata kunci: bahasa daerah, fungsi bahasa, oreng;

\begin{abstract}
The aim of the research is to find and describe the function of oreng in Lamaholot language in Lembata Regency, East N usa Tenggara. The research focused on what aspectsor for what the language was utter ed. Thereby, thetheory used was pragmatic theory that a number of collected data wereanalyzed by considering the context of having utterances. To obtain the data refer ring to the function of oreg, the researcher employed naturalistic method that the sampel s were taken purposively. $\mathrm{N}$ aturalistic research emphasizes on theoriginality of data sources by setting out all social phenomena as sources of collecting data and requiring participant observation. In addition, theresearcher used recording techniqueand conducteparticipation through involved conversation observation method. Emic and ethical approaches were administered to collect the data. The results show that orenghas four pragmatic functions, such as (1) directive, (2) expressive, (3) aesthetic, and (4) communicativefunctions. D irective function is to instruct, prohibit, request, advise, and permit. Expressive function deals with hope and loyalty. A esthetic function belongs to smile, repetition, synecdoche, and personification. Communicative function is to give information.
\end{abstract}

Keyw ords: local ity language, linguistic function, oreng;

\section{PENDAHULUAN}

Oreng adalah nyanyian rakyat etnik Lamahol ot. O reng berbentuk folklore yang terdiri dari kata-kata dan lagu yang beredar secara lisan. Kata-kata dan lagu tersebut merupakan dwitunggal yang tak terpisahkan, demikian menurut pakar folklore, Danandjaja (2002). Dalam tradisi etnik Lamaholot, oreng dapat 
dinyanyikan pada berbagai peristiwa: ritual kelahiran anak, pesta perkawinan adat, ritualritual keagamaan, bahkan pada peristiwa ke matian sekalipun. Dalam peristiwa kematian, oreng menjadi ratapan ekspresi dan ungkapan pamit kepada yang meninggal. Dengan begitu, oreng mengejahwantah menjadi getaran sukma sebagai tanda cinta akan hidup yang dikenang bersama, sambil berucap "selamat jalan" kepada dia yang hendak melewati jalan baru berjumpah dengan Wujud Tertinggi, Tuhan Pencipta Langit dan Bumi (Lera Wulan Tana Ekan). Sebuah perjumpaan yang baru dengan Dia, Pencipta sumber segala berkat, kerahiman, dan kemurahan.

Oreng sebagai khazanah tutur etnik Lamaholot, menjadi bagian kemajemukan bangsa, mencerminkan integralismeyang diikat oleh rasa "ada bersama" dalam satu-kesatuan integral sebagai perwujudan rasa kebangsaan berbangsa dan bernegara. Inilah buah warisan historisitas keyakinan leluhur Lamahol ot yang lestari sekaligus mengimplementasikan keyakinan tradisional akan langit tempat menyembah dan bumi tempat berpijak dalam semangat keagamaan di atas rahim yang sama, yakni lewotanah (kampung halaman).

Sebagai sebuah bangsa kita telah menjejak jalan hidup panjang dengan bersandar pada nilai-nilai kearifan yang telah tertanam dalam bangunan karakter para leluhur. Dipicu kemajuan global, kearifan lokal (local wisdom) pada kelompok masyarakat komunal digaungkan kembali ketika silang-sengkurat persoalan di negeri ini tidak menemukan titik temu. Ada banyak ungkapan dan perilaku yang bermuatan nilai luhur, penuh kearifan pada komunitas lokal, dapat menjadi ikhtiar menyikapi persoalan-persoalan yang muncul. Upaya inilah menjadi bagian dari apropriasi manusia sekarang untuk mengawetkan dan menyelamatkan warisan kultural masa lampau dari sebuah alienasi distansiasi dan ketercerabutan budaya.
Kearifan lokal yang tersebar dan dimiliki oleh hampir setiap etnis tampak secara nyata dalam bahasa-bahasa daerah yang digunakan masing-masing etnis. Kearifan lokal inilah menjadi cultural maxims (Kadarisman, 2009:28), berupa nilai budaya yang dihargai oleh masyarakat. la meresap dan berakar di dalam bahasa dan menjadi sebuah praksis sosial, tumbuh dan mengakar di dalam kelompok-kelompok sosial, bahkan melembaga dalam sistem sosial kemasyarakatan. Bahasa menjadi media untuk mengemas pengetahuan yang tertangkap manah (mind) dalam menghimpun, menyebarkan, dan mewariskan pengetahuan. Bahasa juga menjadi wadah penyimpan informasi, dan berkembang secara simbiosis dengan budaya dan keberlangsungan kehidupan manusia. Oleh karena itu, Piaget mengemukakan bahwa fungsi utama bahasa manusia bukanlah untuk komunikasi saja, melainkan untuk simbolisasi. Simbol adalah representasi kulltural dan ekologis dari realitas, jadi selalu sesuai dengan konteks orang, waktu, dan tempat, dalam hubungannya dengan manah (mind), pikiran, cara berpikir dan bertindak (Geert, 1992:9).

Pada cara pandang yang Iain, Parsons, mengajukan empat sistem yang membingkai kehidupan masyarakat, yaitu sistem organis, psikologis, sistem sosial, dan sistem budaya (via Ujan, 2009:xxi). Dari empat sistem di atas, sistem budayalah yang menjadi akar atau landasan membangun kehidupan bermasyarakat. Oleh karenanya, ada empat simbolisasi yang mendasari sistem budaya tersebut, yaitu: (1) simbolisasi kognitif (ilmu pengetahuan); (2) simbolisasi ekspresif (bahasa-seni); (3) simbolisasi evaluatif (norma-norma); dan (4) simbolisasi pendasaran makna (agama dan ideologi). Sistem dan simbolisasi kehidupan masyarakat sebagai ciri khas dan identitas multikularisme yang mewarnai kehidupan berbangsa seakan tampak tak bernyawa lagi, ketika identitas dimaksud telah tergerus oleh peran negara yang memberlakukan persamaan, Ialu mengabaikan ruang perbedaan yang sesungguhnya. 
Sistem simbol mengkristal dalam masyarakat melalui berbagai kearifan lokal yang dimaknai sebagai sikap, pandangan, dan kemampuan suatu komunitas di dalam mengelola lingkungan rohani dan jasmaninya, yang mampu memberikan komunitas tersebut daya tahan, daya tumbuh, dan daya hidup di dalam wilayah komunitas berada. Kearifan lokal dipandang sebagai jawaban kreatif terhadap situasi geografis-geopolitis, historis, dan situasional yang sedang terjadi di Nusantara ini.

Perubahan nilai menyebabkan juga bahwa nilai-nilai yang dianut oleh suatu generasi belum pasti diterima begitu saja oleh generasi lainnya. Dalam kaitannya dengan manusia sebagai penerus budaya, Ignas Kleden dalam Seminar Nasional di Universitas Flores, 28 Oktober 2011, mengemukakan bahwa ada dua proses yang berlangsung dalam hubungan antara nilai-nilai budaya. Proses pertama dinamakan apropriasi. Proses ini terjadi dengan baik apabila seperangkat nilai budaya diperlakukan dan dihayati oleh seorang individu sebagai nilainya sendiri tentunya berjalan dalam daur kontinuitas yang produktif dan tanpa henti.

Proses kedua yaitu ekspropriasi yaitu kalau seorang individu dengan sengaja menjauhkan diri dari sebuah nilai dan kebudayaannya yang tidak sesuai dengan pandangannya. Baik apropriasi maupun ekspropriasi berlangsung melalui proses belajar dalam kebudayaan (Kleden, 2011:1). Jika masyarakat budaya mengapropriasi dan mengekspropriasi nilainilai budaya dengan baik, maka budaya kita akan tetap lestari dan berkembang ke arah positif. Pelestarian menjadi harapan kita bersama, karena dari cara hidup kita, orang me ngenal siapa kita dan bagaimana budaya kita.

Dalam kondisi yang demikian, masingmasing komunitas perlu bangkit untuk membangun kembali identitas keberbedaan itu se bagai tonggak memperkaya dan mewarnai kehidupan yang multikultural ini, termasuk di dalamnya adalah merekonstruksi budaya, terutama bahasa sebagai khazanah yang kaya fungsi dan makna dengan aneka nilai-nilai kehidupan yang bermakna pula.

Secara teoretis penelitian ini memberikan wacana tentang fungsi bahasa etnis beserta sejumlah nilai di dalamnya. Kajian ini mencoba mengeksplanasi eksistensi bahasa sebagai sebuah sistem internal kepada sebuah eksistensi yang lebih luas, yakni sebagai sebuah medan lapang eksternal. Bahasa telah menyimpan berbagai daya, energia, kekuatan dalam eskalasi kehidupan yang lebih luas.

Secara praktis, kajian ini sangat berguna bagi para pengembang ilmu, terutama para peneliti yang selalu merasa tergelitik untuk mengkaji relasi bahasa dengan masyarakat yang senantiasa mencoba membangun hipotesis-hipotesis baru dalam upaya memperkaya jagat makna keilmuan kebahasaan. Tentunya hasil kajian ini menjadi semacam titik tolok mengeksplanasi pandangan komunitas komunal dan nilai-nilai kemasyarakatan bahasa dengan menjadikan aspek-aspek budaya lisan dan piranti-piranti sosial kemasyarakatan bahasa sebagai landas kaji.

\section{TEORI DAN METODE}

Teori yang digunakan dalam penelitian ini adalah teori pragmatik. Cumings, (2007:2) mengajukan definisi pragmatik yang sangat lengkap, yakni “Pragmatik dapat dianggap berurusan dengan aspek-aspek informasi (dalam pengertian yang paling luas) yang disampaikan melalui bahasa yang (a) tidak dikodekan oleh konvensi yang diterima secara umum dalam bentuk-bentuk linguistik yang digunakan, namun yang (b) juga muncul secara alamiah dari dan tergantung pada makna-makna yang dikodekan secara konvensional dengan konteks tempat penggunaan bentuk-bentuk tersebut."

Pengertian di atas mendasarkan pemahamannya pada empat kata kunci (yang tercetak miring), yakni informasi, dikodekan, konvensi, 
dan konteks. Masing-masing dijelaskan berikut ini.

Informasi merupakan pemrosesan informasi adalah bagian dari proses psikologi kognitif dan intelegensi manusia yang diwujudkan dalam modularitas pikiran itu sendiri. Dengan demikian, informasi yang diberikan hendaknya memiliki relevansi komunikasi dan relevansi kognitif. Dikodekan merupakan aktivitas psikolinguistik yang melibatkan sejumlah proses yang saling berhubungan.

Proses encoding (pengiriman pesan) sebuah pesan hanya dapat dipahami dengan baik, jika ada konteks yang lebih luas yang memungkinkan mitra tutur dapat mendekodekan (mengembalikan) bentuk-bentuk linguistik yang dikomunikasikan. Untuk itu, diperlukan proses inferensial agar memperoleh makna yang dimaksudkan oleh pengi rim pesan atau penutur.

Konvensi merupakan proses memahami bentuk makna tuturan secara bersama-sama. Namun, perlu diingat bahwa makna dalam perspektif semantik berbeda dengan makna dalam perspektif pragmatik, yang lebih melihat ujaran pada akhirnya melahirkan implikatur percakapan dalam suatu konteks tertentu, sehingga bukan merupakan bagian dari konvensi bahasa. Sebab tuturan-tuturan pragmatik lebih bersifat multidisipliner.

Konteks merupakan suatu situasi primer untuk memahami sebuah tuturan secara baik, lengkap, dan utuh. Tanpa konteks, maka tuturan tersebut tidak memiliki makna. Oleh karena itu, konteks memainkan peran yang vital untuk proses rekonstruksi argumen secara valid. Dengan kata lain, konteks memasukkan semua situasi dan hal yang berada di luar teks dan mempengaruhi pemakaian bahasa, seperti partisipan dalam bahasa, situasi di mana teks tersebut diproduksi, fungsi yang dimaksudkan, dan sebagainya.

Leech (1993) memandang pragmatik sebagai studi kebahasaan yang terkait dengan konteks. Pragmatik sebagai ilmu bahasa mempelajari kondisi penggunaan bahasa yang digunakan manusia yang ditentukan oleh konteks yang mewadahi dan melatarbelakangi bahasa itu.Konteks selalu berada bersama situasi di sini, sekarang ini. Konteks dapat berupa konteks yang bersifat sosial dan konteks yang bersifat sosietal.Konteks sosial merupakan konteks yang timbul sebagai akibat dari munculnya interaksi antaranggota masyarakat dalam suatu masyarakat tutur dan budaya tertentu. Sementara itu, konteks sosietal dibangun oleh kedudukan anggota masyarakat dalam situasi-situasi sosial yang ada di dalam masyarakat tutur dan budaya tertentu.

Dalam teorinya tentang fungsi bahasa, Jakobson (via Ola, 2006:65) menekankan pemikiran tradisional Buhler tentang tiga fungsi bahasa, yakni fungsi emotif, fungsi konatif, dan fungsi referensial. Buhler menyebut bahwa sebuah tindak tutur harus memiliki tiga sudut pandang: (1) sudut pandang penutur, tindak tutur adalah suatu gejala (symptom), (2) sudut pandang pendengar, tindak tutur adalah suatu sinyal (signal), dan (3) sudut pandang komunikasi, tindak tutur adalah suatu lambang (symbol). Menurutnya, fungsi dasar bahasa inilah yang menjadi dasar pemakaian bahasa dalam komunikasi yang mencakup pengirim (orang I), penerima (orang II), dan sesuatu (materi) yang dibicarakan oleh pengirim dan penerima.

Penjelasan ringkas di atas mengungkap sesuatu yang lain bahwa pragmatik juga mengemban fungsi sosial kemasyarakatan. Mey (1993) menyebutnya sebagai pragmatik kemasyarakatan. Pragmatik kemasyarakatan berkaitan erat dengan hubungan antara linguistik sebagai ilmu murni dan praktik linguistik sebagaimana diterapkan pada untuk apa orang-orang menggunakan bahasa, serta apa yang mereka lakukan.

Metode pengumpulan data untuk penelitian ini adalah metode naturalistik di mana sampelnya dipilih secara purposif atau purposeful (Alwasilah, 2002:72) atau sampel bertujuan (Moleong, 2009:224). Sampel jenis ini 
sangat memungkinkan peneliti untuk terusmenerus melakukan interpretasi dan interaksi dengan data atau informan. Penelitian naturalistik menekankan pada kealamiahan sumber data dengan mengandalkan seluruh gejala sosial kemasyarakatan sebagai sumber penghimpunan data, sehingga membutuhkan pengamatan berperan serta (participant observation). Selain itu, peneliti menggunakan teknik rekam dan melakukan penyimakan berpartisipasi melalui metode simak libat cakap.

Pengumpulan data juga menyandingkan pendekatan emik dan etik. Digunakannya pendekatan emik karena peneliti berusaha menggali makna sedalam-dalamnya dengan mengacu kepada pandangan warga masyarakat sebagai pemilik budaya lokal, sebagai fenomena dan tonggak budaya dalam masyarakat komunal. Pendekatan emik yang bersumber dari masyarakat komunal tersebut akan dibandingkan pula dengan pendekatan etik, tidak untuk menyesuaikan dan memodifikasi, melainkan menemukan data dan fakta secara objektif dan intensif berdasarkan sudut pandang peneliti tentang fenomena yang sedang diamati (M bete, 2006:30). Ini berarti pemahaman yang diperoleh peneliti dalam studi ini tidak datang dengan sendirinya ataupun dinyatakan langsung oleh realitas budayanya, tetapi direfleksikan, ditafsirkan, atau diinterpretasikan dan direkonstruksi oleh peneliti (Maryaeni, 2005:24) secara terusmenerus, baik dengan data maupun dengan informan. Analisis data dilakukan secara deskriptif atau analisis verbal terhadap hasil pengamatan dan wawancara.

\section{HASIL DAN PEMBAHASAN}

Setelah dilakukan analisis, ditemukan empat fungsi oreng, yakni (1) fungsi direktif, (2) fungsi ekspresif, (3) fungsi estetik, dan (4) fungsi komunikatif. Masing-masing fungsi oreng tersebut diuraikan berikut ini.

\section{Fungsi Direktif}

Bach dan Harnish (via Jumadi, 2005:85), membagi fungsi direktif menjadi lima kelompok, yakni kelompok (a) permintaan, yang mencakup meminta, memohon, mengajak, mendorong, mengundang, dan menekan; (b) pertanyaan, yang mencakup bertanya, berinkuiri, dan menginterogasi; (c) persyaratan, mencakup mensyaratkan, memerintah, mengomando, menuntut, mendikte, mengarahkan, menginstruksikan, dan mengatur; (d) larangan, mencakup melarang dan membatasi; (e) persilaan, mencakup memberi izin, membolehkan, mengabulkan, melepaskan, memperkenankan, memberi wewenang, dan menganugerahi; dan (f) nasihat, mencakup menasihati, memperingatkan, mengusulkan, menyarankan, dan mendorong.

Struktur bentuk direktif biasanya ditandai oleh penanda-penanda formal tertentu. Direktif dalam kelompok permintaan biasanya diwujudkan dalam struktur (a) tuturan yang terdiri atas predikat verba dasar atau adjektiva, atau pun frasa proposisional yang sifatnya tak transitif; dan (b) tuturan dimarkahi oleh berbagai kata tugas modalitas, misalnya mohon, tolong, harap. Direktif kelompok pertanyaan diwujudkan dalam struktur (a) tuturan yang menghendaki jawaban ya atau tidak, (b) tuturan menghendaki satu informasi, (c) tuturan yang menghendaki jawaban berupa perbuatan, (d) tuturan dimarkahi dengan kata-kata tanya, misalnya apa, siapa, berapa, kapan, dan bagaimana dengan partikel kan atau tidak. Modalitas yang sering melekat pada kelompok direktif ini misalnya ayo, coba, dan hendaklah.

Direktif kel ompok larangan juga diwujudkan seperti kelompok permintaan dan perintah. Yang membedakan adalah modalitas yang digunakan. Misalnya, jangan yang diikuti atau tidak oleh partikel -lah. Jenis direktif persilaan atau pengizinan juga sejenis dengan direktif melarang. Hanya saja, modal itas yang biasanya melekat adalah silakan, biarlah, diperkenankan, dan diizinkan. Direktif kelompok nasihat diwujudkan sama dengan direktif kelompok 
pengizinan, dengan menggunakan modalitas mari, harap yang kadang-kadang ayo, coba, hendaknya, dan hendaklah (Rahardi, 2000).

Dari paparan di atas, ditemukan sejumlah fungsi direktif dalamoreng. Fungsi-fungsi direktif dimaksud terdiri atas fungsi memerintah, fungsi melarang, fungsi permintaan, fungsi menasihati, dan fungsi persilaan.

\section{Fungsi Memerintah}

Kutipan [1] di bawah ini berfungsi memerintah. Perintah dari seorang ibu kepada anaknya untuk cepat (segera) pulang ke kampung. Pulang ke tanah kelahiran yang dalam bahasa Lamaholot disebut Lewotanah.

[1] Inaga uda na pradok e pana tueg lewotana rae mai

‘Mama suruh cepat jalan pulang kampung Segera pulang kampung

Kalimat bermodus perintah (imperatif) di atas ditemukan pada"pulang"(pradok). Memang agak memaksa untuk cepat pulang dengan kehadiran kata perintah lainnya, suruh (uda) sebelum kata pulang (pradok). Fungsi ini menjelaskan sekaligus merepresentasikan kuasa seorang ibu kepada anaknya bahwa setelah mendengar perintah ini anak harus segera pulang ke kampung, entah dalam keadaan apapun. Dalam kehidupan nyata, pulang kampung terjadi pada saat merayakan perayaan keagamaan, peristiwa kematian, atau peristiwaperistiwa penting lainnya di dalam suku (klan).

\section{Fungsi Melarang}

Fungsi melarang berisi perintah, tetapi perintah yang negatif, yakni anak tidak boleh berlaku sombong setelah menjadi"orang". Dalam kata Iain, telah menjadi orang yang berhasil dalam pekerjaan.

[2] A ke ara o tite dikabelek

'Jangan tapi kita besar'

Jangan berbesar hati
Tite dipa ara ata dikabelek

'Kita tidak orang besar lebih'

Kita tidak begitu

Larangan di atas tampak pada penggunaan kata jangan (ake), yang merepresentasikan kuasa seorang ibu kepada anaknya. Jangan berlaku atau jangan menjadi seperti itu kalau sudah menjadi "orang besar"(dikabelek). Larangan tersebut muncul dari sebuah pengalaman historis,"kita tidak"(tite dipa), maupun fakta-fakta kekinian tentang bagaimana menjadi orang besar itu. Dalam konteks yang berbeda, fungsi melarang juga terjadi pada sikap pantang terhadap milik orang lain, seperti kutipan di bawah ini.

[3] Gana piranga wata kuma duli

'Makan pantang jagung kuning'

Pantang makan

M enu padanga wai lama suba

'Minum pantang air Lamasuba'

Pantang minum

Eka lera nabo dae

'Jangan matahari hampir dekat'

Kita hampir tiba

Kutipan [3] bernada melarang untuk "pantang"(piranga) dengan menampilkan modalitas "jangan"(ake). Fungsi ini menyaran pada 'hak milik' atau kepemilikan, sekaligus memberikan penegasan tentang usaha dalam mendapatkan sesuatu. Kepemilikan sesuatu yang direpresentasikan melalui "makan"(gana) dan "minum" (menu) harus betul-betul merupakan usaha dan karya sendiri tanpa memperolehnya secara instant atau tiba-tiba. Bahkan, jika kekayaan diperoleh dengan cara-cara yang tidak terpuji dan melanggar norma sosial kemasyarakatan.

\section{Fungsi Permintaan}

Walaupun sama-sama termasuk fungsi direktif, namun fungsi permintaan cenderung lebih rendah daripada perintah. 
[4] M iak take ka hode sole

'Tidak malu pergi ambil dolo'

Mari menari dolo

Sebuah ajakan kebersamaan. Dalam perilaku bertutur, berucap, dan berbahasa manusia sering tidak sadar berlaku salah. Dalam kultur etnik Lamaholot, menari dolo dapat menjadi medium maaf. Dolo adalah sebuah jenis tarian massal dalam etnik Lamaholot yang dilaksanakan dengan membentuk lingkaran, pesertanya adalah laki-laki dan perempuan, orangtua dan remaja. Para anggota tarian berjalan berputar membentuk lingkaran tersebut sambil bernyanyi dan berbalas pantun. Di dalam dolo, orang saling menyapa tentang asalusul dan bisa menyampaikan permohonan maaf kepada orang lain melalui syair-syair yang dilagukan. Dengan demikian, imbauan dan harapan untuk memberikan dan menerimakan maaf antarsesama menjadi sesuatu yang serius. Kutipan [4] mengimplikasikan kewaspadaan dan kehati-hatian dalam membangun komunikasi dan interaksi dengan sesama. Dalam ranah lain, fungsi permintaan dalam oreng tampil seperti di bawah ini.

[5] A ra peten noo inam sudi no mo amam

'Tolong ingat dengan mama harap dengan bapak'

Tolong ingat mama bapak

$\mathrm{N}$ aro tera tua ba lodo lere

'Hampir tua turun rendah'

Hampir tua

Permintaan pada kutipan [5] cenderung lebih rendah, tampak pada modalitas"tolong ingat"(arapeten) dan"kiranya"(sudi). Dua kata ini menjelaskan fungi kuasa permintaan tetapi tidak langsung. Penggunaan kata tolong tidak dianggap bahwa kedudukan mama dan bapak lebih rendah, melainkan bermaksud untuk membangun kesetaraan relasi dalam keluarga antara bapak, mama, dan anak-anak. Kutipan
[4] dan [5] berbeda dengan kutipan [6] di bawah ini.

[6] Sare serut ta'a sare-sare

'Baik sampai dengan baik-baik'

Berbaiklah

Kutipan [6] mengusung tema "maaf"(sare). Maaf keluar dari sebuah "kebeningan nurani" dan "kelimpahan hati" yang menjulur luruslurus bagai "ketela pohon menjalar". Disertai perangkat artefak, kunyit (kumas), kemiri (mirek), disyaratkan dalam ritual ambil kemiri (emu kumas mire) yang ditandakan pada dahi setiap orang (kaka faji) menjadi bukti kuat semangat dan tali persaudaraan. Maaf (sare) yang diidamkan tidak "sekedar" mengucapkan maaf, melainkan melalui sebuah proses "sadar" dari relung hati yang terdalam sehingga mencapai sel-sel hati yang paling dalam (sare serut). Dengan demikian, peristiwa memberikan dan menerimakan maaf juga mendapat ijin dari Tuhan Pencipta langit dan bumi dan direstui oleh leluhur (ina ama koda kewokot).

Konsep kedua adalah minyak (séla). M inyak dalam konteks ini menjadi simbol dan lambang keluhuran, kethulusan, kebeningan, keluncuran pengungkapan dari hati untuk menjalankan maaf (sare). Minyak bukanlah "minyak" yang secara umum digunakan, melainkan minyak yang menjadi sangat istimewa untuk kesempatan khusus, yakni berupa air dan kemiri. Air menyimbolkan kebeningan, kekosongan dan kehampaan hati, dan kemiri melambangkan "penyucian" juga pemuliaan hati. Pemuliaan dan pengantikan (arkaisme) (Latif \& Ibrahim, 1996:147), menjadi jalan menuju kedalaman spiritual yang esoteris. Bahwa beban pikiran telah dikosongkan untuk melangkah dan memulai sesuatu yang baru. Disinilah tradisi adat dipersepsikan sebagai pendalaman komunal masyarakat untuk menguak sentuhan identitas yang lebih berakar, menyentuh, dan bermartabat, sebagai ekspresi populasi masyarakat pemakainya. Dengan demikian, tradisi ini merupakan koherensi spiritual dalam usaha 
(enterprise) pemulihan relasi antara Tuhan, sesama, dan alam.

\section{Fungsi Menasihati}

Fungsi menasihati bertujuan untuk memberikan nasihat atau saran kepada orang Iain. Nasihat atau saran, terlihat pada kutipan [7] di bawah ini.

[7] A ra da dore ku dai nua nulu

'Mereka ikut kata sifat'

Ikuti kata dan perilaku

W eli ara ake o susa nulan di daro

'Ke sana jangan susa sengsara jadi mereka'

Supaya tidak sengsara

Sebagai salah satu bentuk direktif, fungsi menasihati cenderung merepresentasikan kuasa yang humanis. Fungsi menasihati tampak pada"ikuti kata dan perilaku"(dore ku dai nua nulu), dan"jangan"(ake). Fungsi menasi hati tidak menjelaskan kuasa memaksa seorang mama dan bapak kepada anaknya, tapi memberikan motivasi untuk mengikuti atau mencontohi perilaku humanis para orang tua.

Kutipan [7] menampilkan kuasa dan kekuatan sebuah cerita terletak pada kemampuannya untuk menyampaikan nilai-nilai kepada para pendengarnya tidak dengan indoktrinasi. Pendengar cerita memiliki kebebasan untuk mengambil maknanya yang terdapat di dalamnya. Karena itulah ketika seseorang menemukan kecocokan sifat pada tokoh yang diidolakan dalam cerita dapat mempengaruhi hidupnya. Cerita memang menarikkarena itu banyak orang ketika ingin menyampaikan pesan ia menggunakan cerita. Kekuatan cerita terletak pada kemampuannya membawa orang merasa dilibatkan, tidak merasa digurui, dan tidak merasa diindoktrinasi. Maka, ketika cerita menjadi milik pendengarnya memungkinkan terjadinya transformasi cara pandang, sikap, dan tindakan hidup. Hal inilah yang patut diperhatikan dalam proses pembelajaran.
Kutipan [7] juga menyiratkan kuasa dalam ruang publik (Wareing, 1999). Esensi kutipan [7] tentang bagaimana pentingnya bercerita kepada anak. Dikaitkan dengan metode pembelajaran di sekolah, pembelajaran dengan pendekatan cerita bukan hal baru. Jauh sebelum orang mengenal bahasa tulis, cerita telah digunakan dalam proses pembelajaran. Data mengenai hal ini paling tidak dapat kita temukan dalam pengajaran yang dilakukan nenek moyang kita.Seluruh karya dan perjalanannya dilakukan dengan bercerita. Cerita digemari orang tidak mengenal batas usia.

Sebagai misal, infortainment yang disiarkan di media televisi digemari para pemirsa sehingga hampir setiap stasiun televisi dengan judul yang berbeda menayangkan berita-berita kehidupan para aktor atau aktris. Pada dekade 1980-an banyak orang dari anak-anak hingga dewasa terbius cerita radio yang berjudul Saur Sepuh. Orang tua sangat jengkel ketika anaknya diminta untuk belajar tetapi selalu memberi alasan filmyang ditonton seperti Doraemon, Shinchan, Naruto, Satria Baja Hitam, belum sel esai diputar. Cerita dapat menyihir sebagian orang sehingga sering orang mengidentifikasikan dirinya sebagai tokoh cerita tersebut. Ketika seorang anak sangat menggemari cerita mengenai Satria Baja H itam, maka ia dapat mengidentifikasikan dirinya sebagai satria baja hitam. Tidak hanya sampai di situ, baju, kaos, dan asesoris mainannya pun harus berlambangkan Satria Baja Hitam.

\section{Fungsi Persilaan}

Fungsi persilaan (permisives), pada oreng cenderung tampil untuk memberi izin dan petunjuk untuk melakukan perkenal an dengan orang lain.

[8] Diposer aem wara lewo tukan rae mai ‘Balik muka lewat tengah kampung ke sana'

Ke kampung 
Lage rae mai gejek mai jae

'Langkah di sana dan naik sampe di sana' Ke sana

Jae ora-ora lango ara naran

'Di sana atas rumah nama'

Ke rumah

Kutipan [8] bernada imperatif persilaan karena berisikan petunjuk atau tahapan dalam melaksanakan sesuatu. Petunjuk pada kutipan [8] hadir pada kata"balik muka"(diposer aem), "langkah ke sana"(lage rae), dan"di sana"(jae). Secara lahiriah, kutipan ini menyiratkan perintah dari orang yang lebih tua kepada orang yang lebih muda untuk menjalankan sesuatu, tapi masih berada pada batas-batas kesantunan.

Fungsi persilaan yang lain, dipahami se bagai tahapan perkenalan atau memperkenalkan diri dan asal-usul kepada orang lain seperti kutipan [9] di bawah ini.

[9] Inam jae ara mio re ara O la go Genolang 'Mama di sana ataskamu Ola saya Genolang' Mama anak Genolang

Kutipan [9] merupakan sebuah tindakan perkenalan dan informasi informal sebagai prasyarat ketika hendak berkenalan dengan orang Iain."Saya Genolang"(go Genolang) dan"kamu Ola"(Ola), sangat jelas menunjukkan bahwa Genolang adalah komunikator dan Ola adalah komunikan. Kehadiran kata "mama" (inam) diungkapkan oleh Genolang sebagai komunikan bahwa "mama"(inam) dari Ola berasal dari keturunan Genolang.

Kutipan di atas membenarkan pendapat Ullmann (2009, 105-106), bahwa nama sangat erat dengan semantik. Pertama, terdapat hubungan intrinsik antara nama dengan makna. Kedua, adanya kesamaan atau keseIarasan (harmoni) antara nama dan makna, karena bunyi-bunyi tampil secara ekspresif dan jika kebetulan pas ia akan sangat berpotensi ekspresif. Ketiga, antara nama dan makna tergantung konteks, yakni konteks verbal dan konteks situasi.

Nama menjadi penting dalam kehidupan bermasyarakat. Dalam pemberian nama masyarakat etnik Lamaholot, selalu ditempelkan nama suku (klan) pada bagian belakangnya untuk mengetahui secara pasti asal-usal atau muasal orang itu. Tak pelak lagi, semua nama warga etnik Lamahol ot pasti memiliki nama suku atau klan. Selain itu, setiap nama, baik lakilaki atau perempuan, disertai dengan nama kampung (nama nenek atau kakek) untuk mempermudah orang lain mengetahui atau menebak asal wilayah dan turunan orang tersebut. Jadi, nama mempunyai andil yang cukup besar dalam menemukan "kejujuran fantastis", dan "keterbukaan sejati" (Ullman, 2009:109) bagi seseorang dalam membangun karier dan kehidupannya. N ama adal ah bagian dari konsep yang menunjukkan kesadaran se seorang, sehingga nama dapat menimbulkan kesan positif bagi pendengar atau pembaca, nama-nama yang lazim memberi kesan baik dan positif daripada nama-nama yang tidak Iazim. Itulah kenapa banyak seniman atau artis menggunakan nama-nama lain setelah mereka berkiprah dalam profesi mereka (Djojosuroto, 2007:384-385).

Berdasarkan pola penamaan di atas, secara linguistik terdapat sebuah pola penghayatan tradisional secara universal, termasuk masyarakat etnik Lamaholot, yakni (1) nama menunjukkan perilaku atau tingkah laku seseorang; (2) nama menunjukkan identitas seseorang; dan (3) nama menunjukkan eksistensi kemampuan atau potensi seseorang. Pertama, nama menunjukkan perilaku atau tingkah laku seseorang. Kategori ini mencerminkan perilaku dan tingkah laku seseorang. Ketika seseorang sedang berbicara atau berkomunikasi dengan orang lain, lawan atau mitra tuturnya dapat menilai perilaku orang itu. Dari tuturan, misalnya pilihan kata, intonasi, kita dapat mengukur kesopansantunan yang ada pada seseorang pembicara. 
Kedua, nama menunjukkan identitas seseorang. Kategori ini dapat terlihat pada nama yang digunakan. Nama juga membuat masingmasing kita menjadi berbeda antara individu yang satu dengan individu yang lain. Nama dianggap menjadi ciri khas atau identitas yang melekat imanen dan menggambarkan pribadi dan karakter orang. Bahasa yang dikeluarkan dari mulut dan mewujud melalui bunyi-bunyi bahasa dalam bentuk fonem-fonem tidak sekadar sebagai peristiwa alamiah spontanitas, melainkan dapat menunjukkan identitas linguistik seseorang. Identitas linguistik tidak ditafsirkan sebagai identitas individu saja, melainkan menyangkut identitas sosial dan identitas institusional. Melalui bahasa orang dapat menebak dari mana asal seseorang yang sedang berbicara. Ketiga, nama menunjukkan eksistensi kemampuan atau potensi seseorang. Kategori ini mensyaratkan bahwa lewat berbahasa kita dapat mengetahui kemampuan atau potensi seseorang. Kita bisa menelisiknya dari aksen atau tekanan-tekanan kebahasaan yang digunakan. A ksen atau tekanan-tekanan berbahasa kita dapat menafsir kelas sosial atau jenis pendidikan yang pernah dan mungkin sedang dia peroleh (Jones, 1999:196-204).

\section{Fungsi Ekspresif}

Fungsi ekspresif berfungsi untuk mengekspresikan perasaan dan sikap seseorang terhadap keadaan atau sesuatu. Oleh karena itu, fokusnya adalah untuk mengungkapkan keadaan psikologis seseorang yang ditetapkan oleh kondisi kejujuran tentang keadaan sebagaimana yang ditetapkan dalam isi proposisi. Fungsi ekspresif misalnya digunakan untuk mengungkapkan rasa terima kasih, mengucapkan selamat, mengucapkan belasungkawa, menyesalkan, permintaan maaf, dan mengecam. Fungsi ekspresif menyesali, misalnya ditandai oleh penggunaan modalitas sayang, sayang sekali. Fungsi ekspresif mengecam, ditandai oleh penggunaan modalitas tertentu, misalnya kecewa, dan sedih.
Dari paparan di atas, ditemukan sejumlah fungsi ekspresi dalam nyanyian oreng. Fungsifungsi ekspresif dimaksud terdiri atas fungsi harapan, dan fungsi kesetiaan atau loyalitas.

\section{Fungsi Harapan}

Hidup yang sedang dijalani ini juga membutuhkan optimisme dan dibangun dengan berbagai harapan tentang masa depan. Harapan sekecil apapun, termasuk sekadar untuk saling bertemu kembali antarsesama masyarakat, terungkap seperti dalam kutipan di bawah ini.

[10] Ke tuun tue wulan balik pia tode mua mu

'Jadi tahun pulang bulan kembali

Tahun dan bulan baru lanjut lagi'

depan bertemu lagi

Mereka berharap dalam kata "jadi" (ke) bahwa pada suatu saat, entah "tahun pulang" (tuun tue) dan "bulan kembali" (wulan balik), mereka dapat bertemu kembali. Fungsi harapan merepresentasikan kebersamaan yang egaliter, yang satu setara dan sama di antara yang lain. Fungsi harapan juga menjelaskan harapan akan keberadaan orang yang kecil atau lebih rendah. Dalam konteks ini, dapat ditafsirkan sebagai doa, berupa perintah Tuhan kepada umat-Nya, sekaligus merupakan permohonan kepada Tuhan untuk memberikan waktu yang cukup kepada manusia untuk hidup.

\section{Fungsi Kesetiaan atau Loyalitas}

Fungsi kesetiaan mencerminkan ikatan batin atau psikologis antara anggota masyarakat etnik Lamaholot. Kesetiaan atau loyalitas demikian terlihat pada kutipan di bawah ini.

[11] E taro peten tueg lewotana jae te

'Letakkan ingat pulang kampung di sana' Ingat kampung Sudi balik aka to sukusa ekan jae tai

'Harap kembali ke suku bumi ke sana'

Kembali ke suku 
Fungsi kesetiaan mengeksplisitkan kesepakatan konvensional untuk selalu loyal pada kampung (lew otana), dan suku. Fungsi ekspresif dari orang tua kepada anak juga memberikan sebuah harapan tentang masa depan. Konsepsi ini juga menyiratkan kesetiaan atau loyalitas seorang anak kepada orang tua, kakak-adik, suku, dan sesama yang lain.

\section{Fungsi Estetik}

Dari paparan di atas, ditemukan sejumlah fungsi estetik dalam nyanyian oreng. Fungsifungsi estetik dimaksud terdiri atas simile, personifikasi, dan sinekdoki.

\section{Simile}

Gaya simile dalam nyanyian oreng terdapat dalam kutipan di bawah ini.

[12] Wato bisak kana papa rua sesama

'Batu pecah jadi dua bagian'

Batu pecah menjadi dua bagian

Simile dalam kutipan [12] tampak pada kata "batu"(wato). Bukan kebetulan kata "batu"(wato) dihadirkan, tapi ini merupakan sebuah gaya pengandaian untuk menjelaskan dua kelompok yang bertikai dalam sejarah. Pengalaman ini mengajarkan generasi untuk menjalin kembali persahabatan sebagai keluarga besar etnik Lamaholot. Menjaga keseimbangan relasi antara manusia dengan Tuhan, antara sesama, dan dengan alam semesta.

Kutipan di atas menyiratkan kuasa menyatakan kesabaran di tengah tantangan. Ketika berada di tengah alam tropis yang kering masyarakat dan segenap penghuninya dituntut memiliki kesabaran dan giat mengolah dan mengelola alam yang menantang. Alam dengan intensitas curah hujan antara 3-4 bulan dalam setahun sangat mempengaruhi kelangsungan pola tanam dan pola tumbuh tanaman pertanian, baik tanaman umur pendek, maupun tanaman umur panjang.

\section{Personifikasi}

Keeratan relasi manusia etnik Lamaholot dengan kosmos menghasilkan ketergantungan yang kuat terhadap alam dan isinya. Berikut contoh kutipannya.

[13] Besi teti kiwan tuka

'Ketela atas gunung perut'

Ketela tanam di gunung

M ete tipe lita doro

'Bawa petik sulur menjalar'

Menjalar sampai ke bawah

Relasi yang erat dan mengalir antara ciptaan Tuhan di alam raya dipersonifikasi seperti "ketela"(besi). Ini untuk menggambarkan sikap dan perilaku hidup masyarakatnya sebagai "menjalar"(doro). Kutipan ini mengandung fungsi keikhlasan dan kerendahan hati dalam hidup, terutama dalam menjaga relasi baik dengan Tuhan, alam, dan sesama.

Fenomena alamiah tersebut, "ketela"(besi) dan "menjalar"(doro) mewakili dunia empiris akan kenyataan yang sungguh-sungguh ada. Siklus kehidupan manusia Lamahol ot di Imulolong perlu diupayakan untuk mendekati proses peniruan atau mimetik, peneladanan atau pembayangan ke kenyataan. Oleh karena itu, proses mimetik haruslah dijalani secara truthful, benar dan bersifat modest, rendah hati.

Kutipan [13] menegaskan kembali lingkungan alam yang subur. Besi teti kiwan tuka, mete tipe lita doro (ketela di gunung, menjalar sampai ke bawah)."Menjalar ke bawah"(lita doro) adalah penunjuk kesuburan. Ada tanggung jawab memelihara lingkungan alam. Kutipan ini menampilkan sisi lain yang disebut keprihatinan tentang kerusakan alam dan kita sebagai pelakunya. Keprihatinan yang tak pernah selesai menyaksikan, bahkan membaca tanda-tanda alam yang kian parah dan mencemaskan. Kita bisa begitu gampang menyaksikan polusi dan sampah berserakan di manamana. Aktivitas pertambangan, penebangan liar, adalah contoh nyata betapa kita mulai 
resah dengan perubahan pola perilaku dan gaya hidup modern. Resah tentang kondisi alam dan kehidupan generasi masa depan. Alam dan isinya, jika tidak dirawat secara baik hari ini, maka akan mendatangkan bencana masa depan. Bencana itu terjadi pada anak cucu kita yang adalah generasi masa depan bangsa ini. Untuk itulah, menjaga, dan merawat alam dan isinya secara baik dengan pola menanam dan membuat alam tetap hijau me rupakan upaya untuk menjaga dan merawat generasi masa depan secara baik.

Ada pergeseran juga perubahan pola perilaku, pikiran, dan sikap kita terhadap alam. Mungkinkah masih tumbuh sikap dan perilaku untuk memelihara al am yang indah, agar tetap awet dan lestari?A lam yang menjadi tempat pijak dan wadah penafkahan kita justru diabaikan, ditinggalkan, dan dibiarkan lewat jamahan-jamahan tangan nakal kita yang tidak bertanggungjawab. Inilah bentuk keserakahan manusia terhadap alam. Oleh sebab itu, kita menanamkan sikap menjaga dan melestarikan hutan. Merawat bumi agar tetap hijau untuk memberikan kesuburan berlimpah.

\section{Sinekdoki}

Gaya sinekdoki dalam oreng mereferensi pada kumpulan orang atau manusia sebagaimana terdapat pada kutipan-kutipan di bawah ini.

\section{Pars Pro Toto}

Kutipan [14] di bawah ini menggambarkan penyebutan sebagian untuk keseluruhan. Sebagian yang dimaksud adalah"kamu dua "(mio ruam) dan keseluruhan yang dimaksud adalah"kami sembilan orang"(kame ata sifa).

[14] M io ruam budim tuga sare orem tuga dike

'Kamu dua budi baik sekali hati baik juga'

Budi dan hatimu berdua baik

Pars pro toto pada kutipan [14] menjelaskan kebesaran hati seorang bapak dan mama dalam melahirkan, mengasuh, dan membina anak-anaknya. Sebagian,"kamu dua"(mio ruam), merepresentasikan peran dan tanggung jawab seorang bapak dan mama secara universal.

\section{Totem Pro Parte}

Kutipan [15] di bawah ini menggambarkan penyebutan keseluruhan untuk sebagian. Keseluruhan yang dimaksud adalah"sembilan orang"(ata sifa), dan sebagian yang dimaksud adalah"dua orang"(ata rua).

[15] M io ruam jadi kame ata sifa

'Kamu dua lahir kami orang sembilan'

Melahirkan kami sembilan orang

A ta rua mataj rai turu tana

'Orang dua mati pergi tidur tana'

Dua meninggal

A ta rua lolak rai loni ekan

'Orang dua putus pergi bantal kebun'

Pergi mendahuluimu

Totem pro parte pada kutipan [15] menjelaskan perasaan kehilangan "dua orang"(ata rua) dari "sembilan orang"(ata sifa). Perasaan kehilangan anggota keluarga yang dilukiskan pada kutipan di atas, merepresentasikan perasaan manusia sejagat, ketika mengalami kehilangan (baca: kematian) anggota keluarga dan bencana kemanusiaan lainnya. Lebih dalam, totem pro parte menggambarkan kepercayaan manusia universal bahwa hidup merupakan persinggahan sementara pada tapak perjalanan yang maha luas, sehingga harus diisi dengan perbuatan-perbuatan karitatif kemanusiaan dengan sesama.

\section{Fungsi Komunikatif}

Fungsi komunikatif dalam oreng bertujuan untuk membangun interaksi dan relasi kesesamaan sebagaimana pada kutipan-kutipan di bawah ini.

\section{Fungsi Informatif}

Fungsi komunikatif-informatif memastikan pemeliharaan sosial dalam membangun 
komunikasi antara manusia dengan lingkungan yang lebih luas.

[16] Pana pai mio pua-pua

'Jalan datang kamu semua-semua'

Kita semua

Ina ama kaka noo ari

'Mama laki-laki kakak dengan adik'

Perempuan laki-laki, kakak dan adik

Lingkungan yang komunikatif mencerminkan keakraban dalam hidup bermasyarakat. Ini semua adalah bagian dari peradaban budaya yang terus-menerus dijaga, dan dirawat secara akrab. Budaya sopan santun, menghargai orang lain, toleransi, menghormati, cinta sesama, tolong-menolong, kerja sama, dan rela berkorban adalah serpihan-serpihan sikap dan kebaikan dalam pergaulan sosial. Informasi pada kutipan [16] menggambarkan "persatuan" yang dibangun dari dalam keluarga kecil (bapak, mama, dan anak), karena dengan demikian, rasa persatuan tersebut akan dibawa dalam pergaulan yang lebih luas dalam masyarakat sosial.

\section{PENUTUP}

\section{Simpulan}

Bahasa daerah menyimpan sejumlah modal fungsional sosial kultural bagi para penuturnya. Dalam konteks ini, bahasa daerah Lamaholot yang digunakan oleh etnis Lamaholot di Imulolong Kabupaten Lembata, Nusa Tenggara Timur, juga memiliki modal fungsional sosial kultural dimaksud. Hal demikian tersirat dalam oreng yang menjadi obyek penelitian ini. Hasil penelitian menunjukkan bahwa oreng mengandung empat fungsi pragmatik, yakni (1) fungsi direktif, (2) fungsi ekspresif, (3) fungsi estetik, dan (4) fungsi komunikatif. Fungsi direktif meliputi fungsi memerintah, melarang, permintaan, menasihati, dan persilaan. Fungsi ekspresif meliputi fungsi harapan, kesetiaan atau loyalitas.
Fungsi estetik meliputi fungsi simile, sinekdoki, dan personifikasi. Fungsi komunikatif meliputi fungsi informatif.

\section{Saran}

Berkenaan dengan temuan di atas, maka ada beberapa saran yang akan dikemukakan dalam artikel ini.

a. Bagi masyarakat etnis Lamaholot agar tetap melestarikan penggunaan bahasa daerah dalam kehidupan sehari-hari, terutama dalam ritual-ritual adat maupun ritual-ritual lain yang media komunikasinya mengharuskan penggunaan bahasa daerah.

b. Bagi para guru di sekolah untuk memanfaatkan hasil penelitian ini dalam pembelajaran di kelas sebagai upaya melestarikan bahasa daerah.

c. Bagi pemangku kepentingan politik lokal untuk merumuskan regulasi kebahasaan sebagai upaya menjamin kelangsungan bahasa daerah di tengah kepungan bahasa-bahasa asing dan modernisasi bahasa Indonesia sekarang ini.

\section{DAFTAR PUSTAKA}

Cummings, Louise. 2007. Pragmatik: Sebuah Perspektif M ultidisipliner. A bdul Syukur Ibrahim. (Eds). Yogyakarta: Pustaka Pelajar.

Alwasilah, Chaedar. 2002. Pokoknya Kualitatif: D asar-dasar $M$ erancang dan M elakukan Penelitian Kualitatif. Bandung: Pustaka Jaya.

Danandjaja, James. 2002. Folklor Indonesia: IImu Gosip, D ongeng, dan Iain-lain. Jakarta: Grafiti.

Geertz,Cliford.1992. Tafsir

Kebudayaan.Yogyakarta: Kanisius.

Jones, Jason. 1999."Bahasa, Masyarakat dan Kekuasaan". Dalam Linda Thomas \& Shan Wareing (Eds.), Bahasa dan Kelas Sosial.Terjemahan oleh Sunoto,Cs. 2007. 
(hlm. 195-222). Yogyakarta: Pustaka Pelajar.

Kadarisman, Efendi. 2009. M engurai Bahasa M enyibak Budaya. Malang: Penerbit Universitas Negeri Malang.

Jumadi.2005. Representasi Kekuasaan dalam Wacana Kelas. Malang: Program Pascasarjana Universitas Negeri Malang. Disertasi tidak diterbitkan.

Latif, Yudi dan Ibrahim, Subandy Idi. 1996. "Bahasa dan Kekuasaan. Politik Wacana di Panggung Orde Baru". Dalam Latif dan Ibrahim (Eds), Bahasa dan Kekuasaan: Politik W acana di Panggung Orde Baru. Bandung: Mizan.

Maryaeni. 2008. M etode Penelitian Kebudayaan. Jakarta: Bumi Aksara.

M bete, Meko Aron. 2004. "Linguistik Kebudayaan: Rintisan Konsep dan Beberapa Aspek Kajiannya". Dalam Bawa dan Cika (Eds), Bahasa dalam Perspektif Kebudayaan. Denpasar: Universitas Udayana.

Mey, L. Jacob. 1993. Pragmatics: An Introductions. Blackwell: Oxford UK \& Cambridge USA.
Moleong, Lexy. 2009. M etode Penelitian Kualitatif. Bandung: PT. Remaja Rosdakarya.

Ola, Simon Sabon. 2006. "Perubahan Bahasa Lamaholot Dialek Nusa Tadon dalam Ranah Adat dan Perubahan Nilai Budaya."Linguistika. Vol.13, No. 24Maret 2006.

Rahardi, Kunjana. 2005. Pragmatik Kesantunan Imperatif Bahasa Indonesia. Jakarta: Erlangga.

Ujan, A ndre A ta. 2009. “Multikularisme: Belajar Hidup Bersama dalam Perbedaan". Dalam Andre Ata Ujan (Eds.), Keunikan Budaya dan Identitas Komunitas (hlm. ix-xv). Jakarta: PT INDEKS.

Ullmann, Stephen. 2009. Pengantar Semantik. Yogyakarta: Pustaka Pelajar.

Wareing, Shan \&Thomas, Linda. 2007. Bahasa, $M$ asyarakat dan Kekuasaan. Abdul Syukur Ibrahim (Eds.). Yogyakarta: Pustaka Pelajar. 